University of Nebraska - Lincoln

DigitalCommons@University of Nebraska - Lincoln

Publications, Agencies and Staff of the U.S.

Department of Commerce

U.S. Department of Commerce

2007

\title{
Estimating the number of whales entering trade using DNA profiling and capture-recapture analysis of market products
}

C. Scott Baker

Marine Mammal Institute, Hatfield Marine Science Center, Oregon State University, Newport, scott.baker@oregonstate.edu

Justin G. Cooke

School of Biological Sciences, University of Auckland, Private Bag 92019, Auckland, New Zealand

Shane Lavery

Centre for Ecosystem Management Studies, Alexander St. 10, 79261 Gutach, Germany

Merel L. Dalebout

Centre for Ecosystem Management Studies, Alexander St. 10, 79261 Gutach, Germany

Robert L. Brownell Jr.

NMFS Southwest Fisheries Science Centre, rlbcetacea@aol.com

See next page for additional authors

Follow this and additional works at: https://digitalcommons.unl.edu/usdeptcommercepub

Part of the Environmental Sciences Commons

Baker, C. Scott; Cooke, Justin G.; Lavery, Shane; Dalebout, Merel L.; Brownell, Robert L. Jr.; Ma, Yong-Un; Funahashi, Naoko; and Carraher, Colm, "Estimating the number of whales entering trade using DNA profiling and capture-recapture analysis of market products" (2007). Publications, Agencies and Staff of the U.S. Department of Commerce. 87.

https://digitalcommons.unl.edu/usdeptcommercepub/87

This Article is brought to you for free and open access by the U.S. Department of Commerce at DigitalCommons@University of Nebraska - Lincoln. It has been accepted for inclusion in Publications, Agencies and Staff of the U.S. Department of Commerce by an authorized administrator of DigitalCommons@University of Nebraska - Lincoln. 


\section{Authors}

C. Scott Baker, Justin G. Cooke, Shane Lavery, Merel L. Dalebout, Robert L. Brownell Jr., Yong-Un Ma, Naoko Funahashi, and Colm Carraher 


\title{
Estimating the number of whales entering trade using DNA profiling and capture-recapture analysis of market products
}

\author{
C. SCOTT BAKER,${ }^{*+}$ JUSTIN G. COOKE, $\ddagger$ SHANE LAVERY,+ MEREL L. DALEBOUT,,+++ \\ YONG-UN MA, $\$$ NAOKO FUNAHASHI, II COLM CARRAHER + and ROBERT L. BROWNELL JR** \\ ${ }^{*}$ Marine Mammal Institute, Hatfield Marine Science Center, 2030 SE Marine Science Drive, Oregon State University, Newport, OR \\ 97365, USA, +School of Biological Sciences, University of Auckland, Private Bag 92019, Auckland, New Zealand, †Centre for \\ Ecosystem Management Studies, Alexander St. 10, 79261 Gutach, Germany, §Korean Federation for Environmental Movement, 251 \\ Nuha-dong, Jongno-gu, Seoul, 110-806, Republic of Korea, IJapan representative, International Fund for Animal Welfare, 1-2-10 \\ Koyama, HigashiKurume-shi, Tokyo 203-0051, Japan, ${ }^{* * N M F S ~ S o u t h w e s t ~ F i s h e r i e s ~ S c i e n c e ~ C e n t r e, ~} 8604$ La Jolla Shores Drive, La \\ Jolla, CA 92037, USA
}

\begin{abstract}
Surveys of commercial markets combined with molecular taxonomy (i.e. molecular monitoring) provide a means to detect products from illegal, unregulated and/or unreported (IUU) exploitation, including the sale of fisheries bycatch and wild meat (bushmeat). Capture-recapture analyses of market products using DNA profiling have the potential to estimate the total number of individuals entering the market. However, these analyses are not directly analogous to those of living individuals because a 'market individual' does not die suddenly but, instead, remains available for a time in decreasing quantities, rather like the exponential decay of a radioactive isotope. Here we use mitochondrial DNA (mtDNA) sequences and microsatellite genotypes to individually identify products from North Pacific minke whales (Balaenoptera acutorostrata ssp.) purchased in 12 surveys of markets in the Republic of (South) Korea from 1999 to 2003. By applying a novel capture-recapture model with a decay rate parameter to the 205 unique DNA profiles found among 289 products, we estimated that the total number of whales entering trade across the five-year survey period was $827(\mathrm{SE}, 164 ; \mathrm{CV}, \mathbf{0 . 2 0})$ and that the average 'half-life' of products from an individual whale on the market was 1.82 months $(S E, 0.24 ; C V, 0.13)$. Our estimate of whales in trade (reflecting the true numbers killed) was significantly greater than the officially reported bycatch of 458 whales for this period. This unregulated exploitation has serious implications for the survival of this genetically distinct coastal population. Although our capture-recapture model was developed for specific application to the Korean whale-meat markets, the exponential decay function could be modified to improve the estimates of trade in other wildmeat or fisheries markets or abundance of living populations by noninvasive genotyping.
\end{abstract}

Keywords: capture-recapture, fisheries bycatch, IUU exploitation, microsatellites, minke whales

Received 26 August 2006; revision received 10 January 2007; accepted 7 February 2007

\footnotetext{
Note: The first author was responsible for directing market surveys and primary genetic analysis of market products. The second author was responsible for development of the statistical model for capture-recapture analysis.

Correspondence: C. Scott Baker, Fax: +1 541867 0345; E-mail: scott.baker@oregonstate.edu

t+Present address: School of Biological, Earth and Environmental Sciences, University of New South Wales, Sydney, NSW 2052, Australia
}

\begin{abstract}
Introduction
Illegal, unregulated and unreported (IUU) exploitation in the form of incidental fisheries-related 'bycatch' and directed hunting of wildlife for wild meat (bushmeat) poses a major threat to global biodiversity (Milner-Gulland et al. 2003; Lewison et al. 2004). However, estimating the magnitude of these threats, especially on a species-specific scale,
\end{abstract}


remains problematic. For some species, commercial markets represent the end-point in the distribution chain, providing access to products from both legitimate and illegitimate sources of exploitation. Systematic sampling of these markets has the potential to provide direct estimates of the magnitude of this exploitation (e.g. Fa et al. 2000; Fa et al. 2004), especially when combined with genetic identification of products (Baker et al. 2000; Clarke et al. 2004).

Whales, dolphins and porpoises are subject to both regulated and unregulated hunting, as well as fisheries bycatch, in many parts of the world. As a result, the commercial sale of products from these species for human consumption is commonplace in some countries, particularly in Japan and the Republic of (South) Korea (Mills et al. 1997). To date, genetic surveys of whale meat markets have provided information on the species (Baker et al. 1996), stock origin (Baker et al. 2000) and individual identity (Cipriano \& Palumbi 1999; Dalebout et al. 2002) of such products. These surveys have been useful in detecting specific infractions to international agreements, such as the sale of products from protected species (Baker et al. 2002), and determining the minimum number of individual whales represented by multiple products identified by DNA profiling [i.e. microsatellite genotyping and mitochondrial DNA (mtDNA) sequencing, Dalebout et al. 2002]. However, a comprehensive management scheme, such as that under development by the International Whaling Commission (IWC), will require estimates of total whales killed (total takes) to verify official records from member nations and to make allowances for catches by nations without reporting systems (IWC 2006a).

Capture-recapture analysis applied to DNA profiles of market products provides a means of moving beyond a minimum census by using information on replicate products of individual whales (i.e. recapture) to estimate total supply and market throughput. Although it is tempting to treat the appearance and disappearance of market products from an individual whale as a kind of recruitment and mortality in a standard open-population model (Seber 1982), this analogy is misleading. A 'market individual' does not die suddenly but, instead, is sold off (or otherwise disposed of) gradually. Thus, products from an individual whale remain available over time, but in ever decreasing quantities, rather like the exponential decay of a radioactive isotope, which can be expressed in terms of a half-life.

Here we present a novel capture-recapture model for estimating the supply of whales to commercial markets based on individual identification of whale products using DNA profiling. We use this model to estimate the 'total kills over time' for North Pacific minke whales (Balaenoptera acutorostrata ssp.) as represented by trade in Korean markets from 1999 to 2003 . These whales are assumed to originate from a genetically distinct coastal population, referred to by the IWC as the 'J'stock, which was depleted by commercial whaling prior to protection in 1986 (IWC 1997). Although Korea has no program of commercial or scientific whaling, the sale of whales, dolphins and porpoises taken incidentally by entanglement in fishing gear is allowed if the incident is reported to the Maritime Police (Mills et al. 1997). The sale of this bycatch supports a thriving and lucrative market (reportedly up to US\$100 000 wholesale for an adult minke whale, Neff 2004) concentrated in the cities of Busan, Ulsan and Pohang, along the southeastern coast of the Korean peninsula (Kang \& Phipps 2000). The magnitude of the reported bycatch and the uncertainty of other IUU exploitation have serious implications for the survival of this population (IWC 2006b). Official records of whales killed as bycatch in Korea are summarized by the Ministry of Fisheries in the annual submission of National Progress Reports to the IWC. These official reports, along with those from Japan are used by the IWC in models intended to assess the status of this population. However, given direct and indirect evidence that these official records are incomplete (Baker et al. 2000; Dalebout et al. 2002; Baker et al. 2006), there is a growing recognition that uncertainty in catch records must be taken into account in the management of this and other whale populations (IWC 2006a). Our methods of market surveys and estimation by DNA profiling provide one mechanism to account for such uncertainty in the trade in whales (IWC 2005b) and perhaps other species of wildlife sold in traditional or commercial markets.

\section{Methods}

\section{Market surveys}

Whale, dolphin and porpoise products (skin, blubber and meat) were purchased in shops, restaurants and markets in the southeastern coastal cities of Busan, Ulsan and Pohang during 12 surveys from 1999 to 2003. Official records of annual bycatch provided an expectation of the maximum number of whales available for trade during the five-year survey period (Table 1). Experience with Korean markets since 1994, as summarized at a recent workshop of the IWC (IWC 2006a), provided a framework for understanding the dynamics of whale-meat distribution. Products arrive at the three major cities either by landing from the East Sea/ Sea of Japan or by land transport from the west coast (i.e. the Yellow Sea) and ports along the coast north of Pohang. A limited number of wholesalers (approximately 10 were thought to be active during the period of these surveys) then distribute products to approximately 100 retailers in the three cities. Most retail outlets are concentrated in four large fisheries markets (Jagalchi market in Pusan; the Agriculture and Fisheries Market and the Ulsan Fisheries Market, Ulsan; and Juk-do Market in Pohang) or in two traditional whaling ports adjacent to Ulsan and Pohang 
Table 1 Annual fisheries bycatch of North Pacific minke whales in Korea and Japan, as listed in the National Progress Reports to the International Whaling Commission and total number of minke whale products (including pseudo-replicates) purchased on Korean markets

\begin{tabular}{lclll}
\hline Year & $\begin{array}{l}\text { Korean } \\
\text { bycatch }\end{array}$ & $\begin{array}{l}\text { Japanese } \\
\text { bycatch }\end{array}$ & $\begin{array}{l}\text { Progress Report } \\
\text { reference }\end{array}$ & $\begin{array}{l}\text { Korean market } \\
\text { products }\end{array}$ \\
\hline 1999 & 56 & 19 & (IWC 2001c) & 68 (three surveys) \\
2000 & 77 & 29 & (IWC 2002) & 49 (two surveys) \\
2001 & $155^{*}$ & 89 & (IWC 2003a) & 83 (three surveys) \\
2002 & 83 & 116 & (IWC 2004) & 39 (two surveys) \\
2003 & 87 & 137 & (IWC 2005a) & 50 (two surveys) \\
Total & 458 & 390 & & 289 (12 surveys) \\
\hline
\end{tabular}

*Not including five minke whales listed as 'stranded or floating' and assumed to be too decomposed for human consumption.

(Jangsaengpo and Guryongpo, respectively). Previous molecular monitoring confirmed that products from an individual whale were, at times, distributed in multiple shops, markets and cities (Dalebout et al. 2002).

Based on this framework of market dynamics, we attempted to sample systematically the majority of retail outlets displaying or advertising whale meat in the three cities during each survey. Each survey required 1-2 days and included a standard number of shops and market stalls in each of the four fisheries markets and two whaling ports, as well as whale-meat specialty restaurants outside these centres. A total of 65 outlets (e.g. shop, market stall or specialty restaurants) were visited across the five-year study, although variation in whale-meat availability resulted in purchases from a subset of 15-20 outlets on any given survey. The large majority of whale meat sold in Korean markets was thick slices of skin, blubber and meat that has been parboiled and was displayed without refrigeration (IWC 2006a). At each outlet, a range of these prepared but perishable products (from one to six) was purchased depending on variety and volume on display. A much smaller proportion of products, usually sold only at specialty restaurants, consisted of raw red meat. No frozen products were purchased. Each product was given an individual sample code, which was recorded along with a description of the products, the date and location (outlet, market and city) of purchase. One survey (August 1999) was conducted independently by members of TRAFFIC East Asia (Kang \& Phipps 2000) following a similar protocol.

\section{Species identification and DNA profiling}

As in previous surveys of whale-meat markets (Baker \& Palumbi 1994; Baker et al. 1996; Baker et al. 2000; Dalebout et al. 2002), DNA extractions and subsequent amplifications via the polymerase chain reaction (PCR) were conducted using a portable laboratory during annual visits to Korea. To comply with the Convention on International Trade in Endangered Species (CITES), amplified products were isolated from 'native' DNA by agarose gel electrophoresis and band excision, or by biotin labelling and binding the product to streptavidin-coated plates for transport to our home laboratory (Bowen \& Avise 1994; Jones 1994). For samples collected in August 1999, CITES permits were obtained to enable transport of tissue to the Southwest Fisheries Science Center, US National Marine Fisheries Service.

Methods for molecular genetic identification of species and matching of replicate products from individual whales follow those described by Dalebout et al. (2002) and Lavery et al. (2005). In brief, species identity was based on amplification and sequencing of a 464 base pair (bp) fragment of the $5^{\prime}$ end of the mtDNA control region (mt CR). Cycle sequencing reactions were undertaken using ABI Prism Big-Dye Terminator Cycle Sequencing Ready Reaction Kit (v2.0, Perkin-Elmer) and visualized on an ABI 377 or 3100 Automated DNA Sequencer (Applied Biosystems). Sequences were submitted for phylogenetic identification to the web-based program for DNA taxonomy of whales, dolphins and porpoises, www.DNA-surveillance.auckland. ac.nz (Ross et al. 2003). Five microsatellite loci (three tetramers, GATA28, GATA417, and GATA98, from Palsbøll et al. 1997; two dimers, GT23 and GT575, from Bérubé et al. 2000) were amplified from products identified as originating from minke whales in all surveys. Three additional dimeric microsatellite loci were amplified from minke whale products in some surveys (GT211 from Bérubé et al. 2000; EV37 and EV14 from Valsecchi \& Amos 1996). Allele sizes were determined by electrophoresis on an ABI $373 \mathrm{~A}$ or 377 Automated Sequencer, using a $6 \%$ polyacrylamide denaturing gel with an internal size standard (TAMRA 350) in each lane. To allow standardization of allele sizes ('binning') between gels and between years, control individuals representing a range of the most common alleles for each locus were run on all gels. To ensure consistency in the sizing of alleles, all samples were electrophoresed on the ABI platform at least twice. The sex of most products was identified using a multiplex PCR with two pairs of primers that amplify fragments of different size from the ZFX and sry genes, located on the $X$ and $Y$ mammalian chromosomes, respectively (Gilson et al. 1998).

For the purposes of individual identification, genotypes from microsatellite loci, as well as molecular identification of sex and variation in mt CR sequences (haplotypes) were used to develop a 'DNA profile' of each product. DNA profiles were evaluated for matches using the package GENALEX (Peakall \& Smouse 2005) and the probability of identity (PID) for each locus was calculated using МАТсHMAKER 1.0 (Rudnick et al. 2005). 


\section{Capture-recapture model}

In each survey, an individual whale was presumed to be sampled randomly with an intensity proportional to the quantity of its products on the market. A 'sampling event' was defined as a visit to a particular sales outlet (e.g. shop, restaurant or market stall) in a given survey. The DNA profile of a product purchased during a sampling event was considered an individual 'capture'. Replicate products of an individual whale purchased from different outlets in the same survey were considered 'within-survey' recaptures. Replicate products purchased from the same or different outlets in different surveys were considered 'betweensurvey' recaptures. If multiple products purchased in the same sampling event were later found to be derived from the same individual, the products were considered 'pseudoreplicates' and counted only once. For two surveys (May and November, 2001), information on the local outlet was lost due to a computer failure. In these cases, consecutive purchases within a city on a survey day were considered to be a single sampling event.

The quantity of products derived from an individual whale on the market, and hence the Poisson sampling intensity, was presumed to decay exponentially with the length of time the individual was available on the market. The probability that an individual caught in month $t_{1}$ is sampled in a market survey conducted in the same or later month $t_{2}$ is given by:

$p\left(t_{1}, t_{2}\right)=1-\exp \left(-\alpha\left(t_{2}\right) \exp \left(-\beta \cdot\left(t_{2}-t_{1}\right)\right)\right.$

where $\alpha(t)$ is the sampling intensity of new individuals in a survey conducted in month $t$ and $\beta$ is the rate of 'decay' of individuals on the market. The half-life of individuals on the market is $\log _{\mathrm{e}} 2 / \beta$.

The fitting of the model is complicated by the fact that $t_{1}$ for each individual is not observed; hence the likelihood calculation involves integration over this factor. Sensitivity to departures from the assumption of random sampling and the form of the exponential decay function were considered in recent simulations of whale-meat markets based on supply chain dynamics (see below, Influence of heterogeneity).

\section{Parameters}

$\lambda_{t}$ : rate of supply of new individuals to the market in month $t$ (as a Poisson process)

$U_{a, t}:$ expected number of unidentified individuals of 'age' a months on the market in month $t$

$Z_{a, t}=\alpha_{t} \exp (-\beta a)$ : sampling intensity in month $t$ of individuals 'aged' a months (zero in months without a survey) $P_{a, t}=1-\exp \left(-Z_{a, t}\right):$ probability that an individual 'aged' a months will be sampled in month $t$

\section{Data}

$f_{i, t}:$ number of times individual $i$ is sampled in month $t$

$r_{i, t}:=1$ when $f_{i, t}>0$, else 0 . Indicator for whether identified individual $i$ was sampled in month $t$

$T_{i}$ : month for which individual $i$ was first sampled $n$ : total number of identified individuals

$t_{\text {max }}$ : month of final survey

\section{Equations}

$U_{0, t}=\lambda_{t}$

$U_{a+1, t+1}=U_{a, t}\left(1-P_{a, t}\right)$

The full data set consisted of a recapture history for each identified individual, including any multiple samples (recaptures) in the same survey $\left\{f_{i, t}\right\}$. Because analyses using within-survey recaptures are subject to a potentially different set of biasing factors than those using only between-survey recaptures, the reduced data set $\left\{r_{i, t}\right\}$ was also analysed, where within-survey recaptures were not used.

The likelihood of the full data set is given by:

$$
\begin{aligned}
L(f . .)= & \sum_{i=1}^{n} \log \left(\sum_{a} U_{a, T_{i}} \prod_{t=T_{i}}^{t_{\max }} \exp \left(-Z_{a+t-T_{i}, t}\right) Z_{a+t-T_{i}, t} f_{i, t} / f_{i, t} !\right) \\
& +n-\sum_{a} \sum_{t=0}^{t_{\max }} U_{a, t} P_{a, t}
\end{aligned}
$$

where the index $i$ runs over individual recapture histories. The likelihood of the reduced data set using only betweensurvey recaptures is given by:

$$
\begin{aligned}
L(r . .)= & \sum_{i=1}^{n} \log \left(\sum_{a} U_{a, T_{i}} P_{a, T_{i}} \prod_{t=T_{i}+1}^{t_{\max }} P_{a+t-T_{i}, t} r_{i, t}\left(1-P_{a+t-T_{i}, t}\right)^{\left(1-r_{i, t}\right)}\right) \\
& +n-\sum_{a} \sum_{t=0}^{t_{\max }} U_{a, t} P_{a, t}
\end{aligned}
$$

The parameters to be estimated are the sequence of supply rates $\left\{\lambda_{t}\right\}$ and the decay rate parameter $\beta$, with the sampling intensities $\left\{\alpha_{t}\right\}$ as nuisance parameters. Since surveys were not conducted every month, but about 2-3 times per year, it is not reasonable to try to estimate the supply rate in every month. Two models for the $\left\{\lambda_{t}\right\}$ were considered:

(1) $\lambda_{t}=\exp (\mu)$

(2) $\lambda_{t}=\exp \left(\mu+\sigma \cdot v_{t}\right)$ where $v_{t}$ are i.i.d. standard normal random variables. 
Table 2 The total and adjusted (after removal of pseudo-replicates) numbers of North Pacific minke products and individuals collected during 12 surveys of Korean whale-meat markets (March 1999-December 2003)

\begin{tabular}{|c|c|c|c|c|c|c|c|c|c|c|c|c|c|}
\hline \multirow[b]{2}{*}{ Survey date } & \multicolumn{3}{|l|}{1999} & \multicolumn{2}{|l|}{2000} & \multicolumn{3}{|l|}{2001} & \multicolumn{2}{|l|}{2002} & \multicolumn{2}{|l|}{2003} & \multirow[b]{2}{*}{ Total } \\
\hline & Mar & Aug* & Oct & May & Sep & Jan & May & Nov & Jul & Oct & Feb & Dec & \\
\hline \# total minke whale products & 23 & 25 & 20 & 30 & 19 & 31 & 24 & 28 & 17 & 22 & 20 & 30 & 289 \\
\hline \# replicates and pseudo-replicates & 7 & 9 & 6 & 12 & 7 & 13 & 8 & 6 & 1 & 6 & 6 & 3 & 84 \\
\hline$\%$ replicates and pseudo-replicates & $30 \%$ & $36 \%$ & $30 \%$ & $40 \%$ & $37 \%$ & $42 \%$ & $33 \%$ & $21 \%$ & $6 \%$ & $27 \%$ & $30 \%$ & $10 \%$ & $29 \%$ \\
\hline \multicolumn{14}{|l|}{ After exclusion of pseudo-replicates } \\
\hline \# minke whale products & 21 & 21 & 18 & 25 & 14 & 22 & 20 & 22 & 17 & 20 & 19 & 28 & 247 \\
\hline \# within-survey replicates & 5 & 4 & 2 & 4 & 2 & 3 & 0 & 0 & 1 & 4 & 5 & 1 & 31 \\
\hline$\%$ within-survey replicates & $24 \%$ & $19 \%$ & $11 \%$ & $16 \%$ & $14 \%$ & $14 \%$ & $0 \%$ & $0 \%$ & $6 \%$ & $20 \%$ & $26 \%$ & $4 \%$ & $13 \%$ \\
\hline \# between-survey replicatest & - & 1 & 2 & 3 & 3 & 1 & 1 & 0 & 0 & 0 & 0 & 0 & 11 \\
\hline$\%$ within and between replicates & $24 \%$ & $24 \%$ & $22 \%$ & $24 \%$ & $36 \%$ & $18 \%$ & $10 \%$ & $0 \%$ & $6 \%$ & $20 \%$ & $26 \%$ & $4 \%$ & $17 \%$ \\
\hline \# individuals first identified & 16 & 16 & 14 & 18 & 12 & 18 & 16 & 22 & 16 & 16 & 14 & 27 & 205 \\
\hline
\end{tabular}

*Samples provided by US Southwest Fisheries Science Center.

tShown as number of replicate products from individuals found in previous surveys.

Model (1) fits a constant supply rate, whereas model (2) is a random-effects model that fits a mean and variance. Model (2) implies that the monthly variance of the number of individuals entering the market exceeds the mean. The parameters of each model were estimated by maximum likelihood. Selection between models, for a given dataset, was based on the Akaike Information Criterion (AIC).

\section{Results and discussion}

\section{Species and individual identity of products}

Of the 341 products purchased during the 12 surveys (including the 35 reported by Kang \& Phipps 2000), 289 were found to have originated from North Pacific minke whales based on analysis of mt CR sequences (Table 2). The remaining products included two other species of baleen whales (humpback Megaptera novaeangliae and Bryde's Balaenoptera brydei), two species of beaked whales (Baird's Berardius bairdii and Cuvier's Ziphius cavirostris), two species of porpoises (harbour Phocoena phocoena and finless Neophocaena phocaenoides), killer whales (Orcinus orca), false-killer whales (Pseudorca crassidens) and four species of dolphins (short-beaked common Delphinus delphis, Risso's Grampus griseus, Pacific white-sided Lagenorhynchus obliquidens and bottlenose Tursiops truncatus), as well as a small number of products that failed to amplify.

Review of variation in the mt CR, microsatellites, and molecular sex revealed 205 unique DNA profiles with 84 matching profiles from among the 289 minke whale products. Because of degradation due to preparation of whale products (e.g. parboiling) and storage at room temperature prior to purchase, most products could not be unambiguously typed for all eight microsatellite loci. However, most
Table 3 Summary of variation in microsatellite loci, mtDNA control region sequences (number of alleles or haplotypes, observed heterozygosity or haplotype diversity), and the sex ratio for 'market individuals' of North Pacific minke whales found during 12 surveys of Korean whale-meat markets (March 1999_ December 2003)

\begin{tabular}{llcl}
\hline Locus & N (individuals) & alleles & $H_{\mathrm{O}}$ \\
\hline microsatellites: & & & \\
GATA417 & 185 & 6 & 0.631 \\
GATA28 & 205 & 10 & 0.797 \\
GATA98 & 205 & 8 & 0.636 \\
GT575 & 118 & 7 & 0.635 \\
GT23 & 162 & 16 & 0.890 \\
GT211 & 91 & 16 & 0.744 \\
EV37 & 88 & 23 & 0.732 \\
EV14 & 41 & 7 & 0.676 \\
Mt CR: & 205 & 25 & 0.919 \\
sex: & 112 males & - & - \\
& 72 females & & \\
\hline
\end{tabular}

products were amplified for the three tetramers loci and at least one dimer, each of which showed a moderate number of alleles and a moderate level of observed heterozygosity (alleles $=6-16 ; H_{\mathrm{O}}=0.63-0.89 ;$ Table 3 ). The $\mathrm{mt} \mathrm{CR}$ sequences also provided a powerful marker for individual identification, with 25 haplotypes resolved by 36 variable sites in the 464 bp consensus length. All identical DNA profiles matched for the $\mathrm{mt} C R$, sex and at least three microsatellites, with a resulting probability of exclusion for each individual (the probability of a second random individual having that same profile by chance alone) ranging from 0.0000058 to 0.00485 with an average probability of identity of about $1 /$ 8000. On this basis, we assumed that unique DNA profiles 
Table 4 Frequencies of capture-recapture histories for products from individual whales based on DNA profiling during nine surveys of Korean markets from March 1999 to December 2003

\begin{tabular}{lr}
\hline Total market individuals & 205 \\
\hline Captured $1 \times$ in one survey & 172 \\
Captured $2 \times$ in one survey & 18 \\
Captured $3 \times$ in one survey & 4 \\
Captured $4 \times$ in one survey & 1 \\
Captured in two surveys $(1 \times$ each) & 7 \\
Captured in two surveys $(2 \times$ then $1 \times)$ & 2 \\
Capture in three surveys $(1 \times$ each) & 1 \\
Total market captures (excluding pseudo-replicates) & 247 \\
\hline
\end{tabular}

represented the minimum number of individual whales sold on the market (referred to as 'market individuals') and matching profiles represented the distribution of replicate and pseudo-replicate products from each individual.

\section{Capture-recapture estimates of true takes}

After removal of 42 pseudo-replicates (see Methods), there were 247 products representing captures of the 205 market individuals (Table 2). The adjusted number of products purchased and the percentage of replicate products showed considerable variation across surveys but no obvious seasonal trend. There were no within-survey replicates in the May and November 2001 surveys, perhaps because of assumptions made about pseudo-replicates when information on shop location was lost. There was an apparent decline in the number of between-survey replicates in the 2002 and 2003 surveys perhaps due to longer gaps between some surveys (see Future developments for comment on frequency of surveys).

Most market individuals $(n=172)$ were represented by only a single product on a given survey, with smaller numbers found two, three or four times, representing the within-survey recaptures (Table 4). Products from 10 individuals were found in more than one survey (between- survey recaptures): 9 individuals in two surveys and 1 individual in three surveys. Products from two individuals were found twice in the same survey and once in a later survey, contributing to both within- and between-survey recapture datasets. All between-survey recaptures were found in the first survey subsequent to the initial capture (i.e. sequential surveys), except for the single individual found in three surveys (see Supplemental Information).

The modified capture-recapture model provided estimates of total takes of minke whales over the five-year period and the rate at which products from each individual were sold or otherwise disposed of (Table 5). Using the full dataset of within- and between- survey recaptures, the resulting estimate of total takes was $N=827$ (SE, 164; CV, $0.20)$. Using only the between-survey recaptures, the estimate was $N=679$ (SE, 241; CV, 0.35). The estimates of the average half-life of individuals on the market were 1.82 months (SE, 0.24; CV, 0.13) and 1.78 months (SE, 0.32; $\mathrm{CV}, 0.18$ ) for the full and between-survey only datasets, respectively. The two sets of estimates were not significantly different from each other, but as expected the estimate using the full dataset had lower variance because more information was used. When the within-survey recaptures were included (i.e. the full dataset), the model allowing for additional variance in the monthly supply rate yielded a significantly better fit $(\triangle \mathrm{AIC}>5)$. As such, we considered the estimate of $N=827$ (SE, 164; CV, 0.20), based on the full dataset (Model 2), to be the 'best' estimate of total takes of minke whales on the Korean markets for the period of 1999-2003, subject to the potential biases discussed below.

\section{Comparison to reported bycatch and management implications}

National Progress Reports of the Republic of Korea to the IWC list a total of 458 minke whales killed by fisheries entanglement during the calendar years of 1999-2003 (Table 1). This total is significantly less than our capturerecapture estimate of $N=827$, using the combined withinand between-survey datasets. Considering the standard

Table 5 Capture-recapture estimates of total takes and market decay of North Pacific minke whales based on market surveys from March 1999 to December 2003

\begin{tabular}{|c|c|c|c|c|c|c|c|c|}
\hline \multirow{3}{*}{$\begin{array}{l}\text { Recapture data sets } \\
\text { Model }\end{array}$} & \multicolumn{4}{|c|}{ Within- and between-surveys } & \multicolumn{4}{|c|}{ Between-survey } \\
\hline & \multicolumn{2}{|l|}{1} & \multicolumn{2}{|l|}{2} & \multicolumn{2}{|l|}{1} & \multicolumn{2}{|l|}{2} \\
\hline & Estimate & $S E(C V)$ & Estimate & $S E(C V)$ & Estimate & $S E(C V)$ & Estimate & $S E(C V)$ \\
\hline Total takes & 753 & $129(0.17)$ & 827 & $164(0.20)$ & 704 & $172(0.19)$ & 679 & $241(0.35)$ \\
\hline Monthly decay rate & 0.35 & $0.05(0.14)$ & 0.38 & $0.05(0.13)$ & 0.37 & $0.05(0.13)$ & 0.39 & $0.07(0.18)$ \\
\hline Half-life (months) & 1.98 & $0.28(0.14$ & 1.82 & $0.24(0.13)$ & 1.87 & $0.25(0.13)$ & 1.78 & $0.32(0.18)$ \\
\hline Sigma & & & 1.20 & & & & 0.70 & \\
\hline AIC & 653.57 & & 647.20 & & 752.99 & & 752.07 & \\
\hline
\end{tabular}


error of our estimate (SE 164), official records appear to account for only about $46 \%-70 \%$ of the true takes (including IUU). Interestingly, the highest reported annual take of 155 minke whales (in 2001) is close to the expected average annual take from our capture-recapture estimate. Although reasons for variation in the annual reported takes have not received much attention by the IWC, we suggest that possibilities should include incomplete reporting and the influence of periodic enforcement efforts (e.g. arrests for illegal whaling).

Our estimates of whales killed (true takes) have serious implications for the survival of the population (or populations, see Lavery et al. 2005) of minke whales in the coastal waters of Korea and Japan. Previous efforts to model the impact of total exploitation on this stock focused on the under-reporting of takes by the Government of Japan, while assuming that the relatively high reported takes by Korea were accurate (Baker et al. 2000). At that time, the model predicted a decline towards extinction for the population over the next few decades based on an estimated range of true takes from 100 to 150/year for Japan and Korea combined. Although originally rejected as implausibly high by officials of both governments during meetings of the IWC (Baker 2002), it is clear that these estimates of true takes must now be rejected as implausibly low. In 2001, Japan modified its domestic regulations to allow fisherman to kill and sell products from entangled whales, if the carcass was registered with the Ministry of Fisheries (Anonymous 2001). Following this modification, the reporting of bycatch increased from less than 30/year to more than 100/year (Table 1). The higher reported takes of recent years are approximately equal to the estimates from molecular monitoring of Japanese markets (Baker et al. 2000) and extrapolation of fishing effort (Tobayama et al. 1992) in years prior to this change in regulation, suggesting that reporting has improved but that bycatch was at similarly high levels prior to 2001. Adding the reported bycatch from Japan to our current estimate from the Korea markets now suggests that the annual take of coastal minke whales is roughly twice as large as considered in the previous population model (i.e. 200-300/year for Japan and Korea combined).

As a result of concern about the impact of bycatch in Korean and Japanese coastal waters, the IWC initiated an in-depth assessment of minke whales in the Yellow Sea and East Sea/Sea of Japan. Following a review of available information at the annual meeting in 2005, the Scientific Committee noted that 'evidence presented to date (in 2005) showing relatively low abundance and high bycatch had not allayed this concern' (IWC 2006b). Despite these concerns, however, the governments of Japan and Korea have taken no steps to reduce the levels of bycatch of coastal minke whales and the future of this distinct population seems grim.

\section{Influence of heterogeneity in market surveys}

Our capture-recapture method is based on the assumption that individual whales were sampled randomly from the population in proportion to the quantity of their products still on the market, and that the latter could be represented by a simple exponential decay model. If the sampling process deviated from these assumptions, our supply estimates could be either negatively biased (if repeated sampling of the same individual was more likely than expected under random sampling) or positively biased (if repeated sampling of the same individual was less likely than expected under random sampling).

In market surveys, a number of potential factors make repeated sampling of individuals more likely than under pure random sampling: (i) heterogeneity in the quantity of marketed products per individual, due to variation in body mass (i.e. size) and in the proportion of body mass that is utilized; (ii) heterogeneity in the accessibility of products from individual whales due to specific, nonrandom trade routes or distribution networks; (iii) heterogeneity in the volume of sales from individual outlets (i.e. high-volume and low-volume outlets) relative to the rates of market sampling; (iv) heterogeneity in the geographical distribution of products from individual whales; (v) heterogeneity in the half-life of individuals on the market due to differences in storage conditions (although long-term, frozen storage of whale meat seems to be uncommon in Korea, Kang \& Phipps 2000); and (vi) false matching of products derived from different individuals due to low probability of exclusion from DNA profiles of degraded products.

All the above factors are likely to lead to a negative bias in supply estimates for both within- and between-survey recaptures. However, within-survey recapture estimates could, in principle, be positively biased if products from each individual are supplied to only a limited number of outlets, resulting in fewer within-survey recaptures than expected under random sampling. In the extreme case, products from each individual could be supplied to only one outlet.

The sensitivity of the capture-recapture model to these sources of heterogeneity and to the form of the exponential decay function was examined recently with simulations based on the assumed structure of the Korean whale-meat markets (Leaper \& Cooke 2006). Following the logic of supply chain models (van der Zee \& van der Vorst 2005) used to study distribution of fresh food, Leaper \& Cooke (2006) considered variability in the sizes of whales, the seasonality of supply, distribution pathways and retail demand, as well as sample size and frequency of surveys. The simulations confirmed that the capture-recapture model, using both within- and between-survey recaptures, yielded reliable, but conservative (negatively biased), estimates of the number 
of whales in trade and the half-life of these products. In most of the simulation scenarios, the magnitude of this negative bias ranged from 12 to $24 \%$ for estimates of whales in trade. Estimates excluding within-survey replicates showed less bias but greater variance (Leaper \& Cooke 2006).

\section{Future developments for monitoring of bycatch and whaling}

A key factor in the design of future surveys of whale-meat markets would be the trade-off in the frequency of surveys and the number of samples collected on each survey. For our estimate from the full dataset (using within- and between-survey replicates), precision (as measured by the coefficient of variation, $\mathrm{CV}=0.20$ ) was comparable to that of many abundance estimates of living whale populations used by the IWC. However, precision was poorer for estimates from the between-survey only dataset $(\mathrm{CV}=0.35$ from Model 1) because of the small number of recaptures. Given an estimated average half-life of less than two months, the six-month interval between some of the surveys was presumably too long to expect recaptures. Here, the simulations based on the assumed structure of the Korean whale-meat markets give clear guidance (Leaper \& Cooke 2006): surveys conducted nine weeks apart always performed better than those conducted twice as far apart, even with only half the sample size for each survey.

Efforts to improve monitoring and detection of IUU exploitation of cetaceans in Korea and elsewhere could be enhanced greatly by the establishment of a diagnostic 'DNA register' for all whales destined for commercial markets (IWC 1998; Dizon et al. 2000). Such a register would include information from a standard set of molecular markers (e.g. mtDNA for species identification and microsatellite loci for individual identification) derived from tissue samples collected from all directed hunting or bycatch of whales. The DNA profile of any market product could then be compared to information in this register. If the market product matched a registered take, the product could be considered authorized or 'legal'. If no match is found to the register, the product would be considered 'illegal'. With regular market surveys, a DNA register could also be used to estimate the proportion of individuals that were derived from recorded catches and those that were unreported and, consequently, of suspect origin (IWC 2005b). Although Japan and Norway have committed to the development of such registers (IWC 1998), both countries oppose implementation of market surveys as a component of any scheme for observation and monitoring of whaling (IWC 2001a; IWC 2001b). Korea has made efforts to improve the collection of biological samples from bycaught whales (IWC 2006a) although, to our knowledge, it has not committed to developing a DNA register.

\section{Other applications of 'death and decay' models}

Although the capture-recapture model presented here was developed for specific application to the Korean whalemeat markets, the exponential decay function could be applied to estimation of total takes in other wildmeat markets (Milner-Gulland et al. 2003). Surveys of wildmeat markets often rely on identification of species from visual examination of whole carcasses (e.g. Fa et al. 2000). Such an approach is likely to under-represent large animals that are butchered before transport to market. By including molecular identification and genotyping of butchered products in market surveys it should be possible to improve estimates of the true takes and track the origins and supply routes for large species such as the hippopotamus (Hippopotamus amphibious), which is thought to have experienced a 95\% decline in abundance as a result of intensive hunting and demand from wildmeat markets (Lewison \& BCTF 2004.). Surveys of other wild meat markets could also benefit from supply chain simulations similar to those designed for the Korean whale-meat markets (Leaper \& Cooke 2006), provided some estimate of half-life could be derived from either product capture-recapture or some analysis of market behaviour. Pilot studies and simulations could assist in efficient design in the trade-off between of sample size and survey frequency, and in selecting the functional form most appropriate for the modelling the exponential decay of products from species of different sizes.

Our model is just one example of a new class of capturerecapture models in which the unit of sampling is not the individual but, rather, one or more 'products' from an individual (Lukacs \& Burnham 2005). For example, heterogeneity due to differences in the timing and frequency of multiple noninvasive samples, such as hair, feathers or faeces, is likely to bias estimates of population abundance using DNA profiling and standard capture-recapture analysis (e.g. Kohn \& Wayne 1997). Corresponding models could be developed to help account for this form of heterogeneity and for the increasing number of studies where there is a process of decay in either the quantity or quality of samples (Taberlet et al. 1999).

\section{Acknowledgements}

We thank the Korean Federation of Environmental Movement and John Frizell of Greenpeace International for sample collection and logistic support in Korea. MLD was supported by a University of New South Wales Vice-Chancellor's Postdoctoral Fellowship. K. Robertson, Southwest Fisheries Science Center of the US National Marine Fisheries Service, conducted the genetic analysis of samples from the August 1999 survey. C. Brooks assisted in a final review of the microsatellite genotypes. R. Wayne suggested the potential for application of decay models to estimation of abundance using genotyping of faeces. We thank B. Taylor, S. Palumbi and two 
anonymous reviewers for comments on an earlier draft of the manuscript. Funding for the analysis of the survey results was provided by the International Fund for Animal Welfare.

\section{References}

Anonymous (2001) Japanese Ministry of Agriculture, Forestry and Fisheries 20 April 2001 revisions to its Ministerial Ordinance No. 92, to take effect 1 July 2001. http://www.maff.go.jp/mud/ 410.html.

Baker CS (2002) Appendix 13: Uncertainty and plausibility of incidental takes for RMP implementation simulation trials for North Pacific minke whales. Journal of Cetacean Research and Management, 4 (Suppl.), 138-139.

Baker CS, Palumbi SR (1994) Which whales are hunted? A molecular genetic approach to monitoring whaling. Science, 265, 1538-1539.

Baker CS, Cipriano F, Palumbi SR (1996) Molecular genetic identification of whale and dolphin products from commercial markets in Korea and Japan. Molecular Ecology, 5, 671-685.

Baker CS, Lento GM, Cipriano F, Palumbi SR (2000) Predicted decline of protected whales based on molecular genetic monitoring of Japanese and Korean markets. Proceedings of the Royal Society of, London Series B, 267, 1191-1199.

Baker CS, Dalebout ML, Lento GM, Funahashi N (2002) Gray whale products sold in commercial markets along the Pacific Coast of Japan. Marine Mammal Science, 18, 295-300.

Baker CS, Lukoschek V, Lavery S et al. (2006) Incomplete reporting of whale, dolphin and porpoise 'bycatch' revealed by molecular monitoring of Korean markets. Animal Conservation, 9, 474-482.

Bérubé M, Jorgensen H, McEwing R, Palsbøll PJ (2000) Polymorphic di-nucleotide microsatellite loci isolated from the humpback whale, Megaptera novaeangliae. Molecular Ecology, 9, 2155-2234.

Bowen BW, Avise JC (1994) Conservation research and the legal status of PCR products. Science, 266, 713.

Cipriano F, Palumbi SR (1999) Genetic tracking of a protected whale. Nature, 397, 307-308.

Clarke SC, McAllister MK, Michielsens CGJ (2004) Estimates of shark species composition and numbers associated with the shark fin trade based on Hong Kong auction data. Journal of Northwest Atlantic Fisheries Science, 35, 1-13.

Dalebout ML, Lento GM, Cipriano F, Funahashi N, Baker CS (2002) How many protected minke whales are sold in Japan and Korea? A census by DNA profiling. Animal Conservation, 5, 143-152.

Dizon A, Baker S, Cipriano F et al. (2000) Molecular genetic identification of whales, dolphins, and porpoises: proceedings of a workshop on the forensic use of molecular techniques to identify wildlife products in the marketplace, p. 52pp.+xi. U.S. Department of Commerce, NOAA Technical Memorandum, La Jolla, California.

Fa JE, Yuste JEG, Castelo R (2000) Bushmeat markets on Bioko Island as a measure of hunting pressure. Conservation Biology, 14, 1602-1613.

Fa JE, Johnson PJ, Dupain J et al. (2004) Sampling effort and dynamics of bushmeat markets. Animal Conservation, 7, 409-416.

Gilson A, Syvanen M, Levine K, Banks J (1998) Deer gender determination by polymerase chain reaction: validation study and application to tissues, bloodstains, and hair forensic samples from California. California Fish and Game, 84, 159-169.

IWC (1997) Report of the Scientific Committee, Annex J. Report of the working group on North Pacific minke whale trials. Reports of the International Whaling Commission, 47, 203-226.
IWC (1998) Report of the Scientific Committee, Annex Q. Report of the working group on proposed specifications for a Norwegian DNA database register for minke whales. Reports of the International Whaling Commission, 49, 287-289.

IWC (2001a) Annex I: Report of the working group on stock definition, Appendix 2 Statement from the Government of Japan concerning DNA identification and tracking of whale products. Journal of Cetacean Research and Management, 3 (Suppl.), 237.

IWC (2001b) Annex I: Report of the working group on stock definition, Appendix 3 Statement from the Government of Norway concerning DNA identification and tracking of whale products. Journal of Cetacean Research and Management, 3 (Suppl.), 237.

IWC (2001c) Annex R: Summary of Information from Progress Reports (Calendar year 1999). Journal of Cetacean Research and Management, 3 (Suppl.), 341-355.

IWC (2002) Annex O: Summary of Information from Progress Reports (Calendar year 2000). Journal of Cetacean Research and Management, 4 (Suppl.), 377-390.

IWC (2003) Annex O: Summary of Information from Progress Reports (Calendar year 2001). Journal of Cetacean Research and Management, 5 (Suppl.), 426-444.

IWC (2004) Annex R: Summary of Information from Progress Reports (Calendar year 2002). Journal of Cetacean Research and Management, 6 (Suppl.), 375-397.

IWC (2005a) Annex Q: Summary of Information from Progress Reports (Calendar year 2003). Journal of Cetacean Research and Management, 7 (Suppl.), 355-384.

IWC (2005b) Report of the Specialist Group on the DNA Register/ Market Sampling Scheme Approach (SGDNA). IWC/M05/ RMSWG 5, available from the Secretariat, International Whaling Commission, The Red House, 135 Station Road, Impington, Cambridge, CB4 9NP UK.

IWC (2006a) Report of the Scientific Committee, Annex J: Working Group on Estimation of Bycatch and other Human-induced Mortality (BC). Journal of Cetacean Research and Management, 8 (Suppl.), 177-184.

IWC (2006b) Report of the Scientific Committee, Section 10.2 In-depth assessment of western N. Pacific common minke whales, with a focus on J stock. Journal of Cetacean Research and Management, 8 (Suppl.), 22-25.

Jones M (1994) PCR products and CITES. Science, 266, 1930.

Kang S, Phipps M (2000) A survey of whale meat markets along South Korea's coast. TRAFFIC East Asia, Hong Kong.

Kohn MH, Wayne RK (1997) Facts from faeces revisited. Trends in Ecology and Evolution, 12, 223-227.

Lavery S, Baker CS, Dalebout ML et al. (2005) Hidden population structure and undocumented exploitation of Western North Pacific minke whales inferred from genetic analysis of Japanese and Korean market products. Report (SC/57/NPM5) to the Scientific Committee of the International Whaling Commission, The Red House, 135 Station Road, Impington, Cambridge CB4 9NP, UK.

Leaper R, Cooke J (2006) Preliminary simulations of whale meat markets to investigate sensitivity of sampling design to assumptions about market structure. Report (SC/58/BC8) to the Scientific Committee of the International Whaling Commission, The Red House, 135 Station Road, Impington, Cambridge, CB4 9NP UK (available from the office of the IWC, www.iwcoffice.org).

Lewison R, BCTF (2004) Bushmeat Crisis Task Force Fact Sheet: Hippos and the African Bushmeat Trade. Bushmeat Crisis Task Force. Available from: www.bushmeat.org/docs, Washington, DC. 
Lewison RL, Crowder LB, Read AJ, Freeman SA (2004) Understanding impacts of fisheries bycatch on marine megafauna. Trends in Ecology and Evolution, 19, 598-604.

Lukacs PM, Burnham KP (2005) Review of capture-recapture methods applicable to noninvasive genetic sampling. Molecular Ecology, 14, 3909-3919.

Mills J, Ishirhara A, Sakaguchi I et al. (1997) Whale meat trade in East Asia: a review of the markets in 1997. TRAFFIC International, Cambridge (UK ISBN 185850 1253).

Milner-Gulland EJ, Bennett EL, SCB 2002 Annual Meeting Wild Meat Group (2003) Wild meat: the bigger picture. Trends in Ecology and Evolution, 18, 351-357.

Neff R (2004) A whale of a tale. June 4. In: The Korea Times.

Palsbøll PJ, Bérubé M, Larsen AH, Jørgensen H (1997) Primers for the amplification of tri- and tetramer microsatellite loci in baleen whales. Molecular Ecology, 6, 893-895.

Peakall R, Smouse PE (2005) Genalex 6: genetic analysis in Excel. Population genetic software for teaching and research. Molecular Ecology Notes, 6, 288-295.

Ross HA, Lento GM, Dalebout ML et al. (2003) DNA surveillance: web-based molecular identification of whales, dolphins and porpoises. Journal of Heredity, 94, 111-114.

Rudnick JA, Katzner TE, Bragin EA, Rhodes OE Jr, DeWoody JA (2005) Using naturally shed feathers for individual identification, genetic parentage analyses, and population monitoring in an endangered Eastern imperial eagle (Aquila heliaca) population from Kazakhstan. Molecular Ecology, 14, 2959-2967.

Seber GAF (1982) The Estimation of Animal Abundance and Related Parameters, 2nd edn. Arnold, London.

Taberlet P, Waits LP, Luikart G (1999) Noninvasive genetic sampling: look before you leap. Trends in Ecology and Evolution, 14, 323-327.

Tobayama T, Yanagisawa F, Kasuya T (1992) Incidental take of minke whales in Japanese trap nets. Reports of the International Whaling Commission, 42, 433-436.
Valsecchi E, Amos W (1996) Microsatellite markers for the study of cetacean populations. Molecular Ecology, 5, 151-156.

van der Zee DJ, van der Vorst JGAJ (2005) A modeling framework for supply chain simulation: opportunities for improved decision making. Decision Sciences, 36, 65-95.

This work is the result of long-term collaboration among scientists and representatives of nongovernment organizations committed to the conservation of protected species and the improved monitoring of trade in exploited species. The multidisciplinary team includes expertise in molecular ecology, conservation genetics, the dynamics of whale-meat markets in East Asia, the dynamics of whale populations, and the history of whaling. Several authors have acted as national delegates or invited participants to the Scientific Committee of the International Whaling Commission.

\section{Supplementary material}

The following supplementary material is available for this article:

Table S1 Frequencies of sampling histories (i.e., capture-recapture records) for whale-meat products purchased in each of the nine surveys of Korean markets from 1999 to 2003.

This material is available as part of the online article from: http://www.blackwell-synergy.com/doi/abs/ 10.1111/j.1365-294X.2007.03317.x

(This link will take you to the article abstract).

Please note: Blackwell Publishing are not responsible for the content or functionality of any supplementary materials supplied by the authors. Any queries (other than missing material) should be directed to the corresponding author for the article. 